\title{
26. RESULTS OF LEG 30 AND THE GEOLOGIC HISTORY OF THE SOUTHWEST PACIFIC ARC AND MARGINAL SEA COMPLEX
}

\author{
Gordon H. Packham, Department of Geology and Geophysics, University of Sydney, NSW, Australia \\ and \\ James E. Andrews, Department of Oceanography, University of Hawaii, Honolulu, Hawaii
}

\section{INTRODUCTION}

To a large degree, Leg 30 was concerned with the origins of the western Pacific marginal basins, lying within the confines of the India plate (Figure 1). On the bathymetric map of the southwest Pacific there is a bewildering pattern of basins and ridges with small island chains that lie near the junction between the India and Pacific plates. These features evolved in late Mesozoic and Cenozoic.

In the last few years, several hypotheses for the origin of marginal seas have been proposed (Karig, 1971; Packham and Falvey, 1971; Moberly, 1972). All of these hypotheses propose that arc migration is in some way related to the formation of the new oceanic crust of the basins, and that the genesis of this crust was different from that of mid-ocean ridges although the seismic layering of the crust was similar to that of the ocean basins. Karig (1971) proposed that the splitting of island arcs was responsible for the formation of the basins, the driving force being a "thermal diapir" rising from the benioff Zone associated with the arc. Packham and Falvey (1971) suggested that the crust was formed by the injection of the asthenosphere into the region behind the arc moving the arc forward. The spreading would probably be asymmetrical with the spreading center behind the arc. Moberly (1972) proposed that the arc moves forward due to the gravitational sinking and retreat of the inflexion point of the lithospheric slab on the oceanic side of the arc. That is, the trajectory of the sinking plate is steeper than the angle of the plate.

Although the mechanism remains unclear, in our view the Paleogene arc and basin systems of the southwest Pacific can be explained by contributions of material from the asthenosphere developing areas of new sea floor along the interacting plate boundaries. The migration of island arcs is a function of these processes.

Analysis of the geometry of plate motion is dependent on the mapping of magnetic anomalies and fracture zones related to spreading. Apart from in the Tasman Basin, which is not regarded by us as a marginal sea, no such magnetic anomalies have been mapped in the Paleogene basins of the region. But anomaly patterns have been detected in some of the younger basins of the region: the Lau Basin (Sclater et al., 1972); the Fiji Plateau (Chase, 1971; Luyendyk et al., 1974); and the Woodlark Basin (Luyendyk et al., 1973). In all cases the anomaly pattern is not as simple as that found adjacent to mid-ocean ridges.

Because magnetic anomaly patterns capable of kinematic analysis are either absent or poorly known within the marginal basins drilled, the geological histories of the basins have to be based largely on litho- logical sampling, seismic profiling, and major plate motions. Drilling by the Deep Sea Drilling Project has been carried out in the region on Legs 21 and 30 (Figures 1 and 2). The results of Leg 21 have been presented previously (Burns, Andrew, et al., 1972, Burns, Andrews, et al., 1973). A preliminary account of the results of Leg 30 has been presented by Andrews, Packham, et al., 1973. Details of the drilling are presented in this volume. After reviewing the tectonic implications of Leg 30 drilling results, it is our present purpose to present an interpretation of the regional geological history and make some comments on the origin of the marginal basins.

\section{DISCUSSION OF DRILLING RESULTS}

The sequence at Site 285 (Chapter 3, this volume) in the South Fiji Basin parallels that drilled to the northeast at Site 205 in that a coarse ashy succession is followed by a biogenic section and then by abyssal clay. However, the rhythmic volcaniclastic sequences of Site 285 do not occur at Site 205. Structural ridges seen crossing the seismic profiles from New Zealand to Site 285 (Figure 3, in pocket at back of volume) pond clastic sedimentation from the south. It is suggested that the source of the volcanic sediment at Site 285 was the Lau Ridge. This also conforms to the present slope of the sea floor.

It would appear that the South Fiji Basin may have formed in the Eocene and Oligocene. Its present basement pattern may have been enhanced or developed by pre-middle Miocene tectonism (see Packham and Terrill, this volume). Late Oligocene ashy biogenic sediments deposited near the depth of total solution of planktonic forams at Site 205 may be present beneath intrusive diabase at Site 285 . The early Miocene record is not preserved at either site. In middle to late Miocene time, intermediate to acid volcanism developed, and pyroclastics were deposited near the Lau Ridge (Site 205) and transported to the west (Site 285) and deposited in the deeper parts of the basin. Biogenic deposits appear in the latest Miocene, and coincident tectonism exposing older material resulted in redeposition of Oligocene to early Miocene material in the early Pliocene section at Site 285. Later sediments (latest Pliocene to Recent) were deposited below nannofossil solution depth (depth of total solution of nannofossils, which is in turn below foram solution depth), probably as a result of basin subsidence caused by lithosphere cooling. Continued minor faulting is apparent on seismic profiles in some of the local basins.

In the New Hebrides Basin at Site 286 (see Chapter 4, this volume) basaltic flows were extruded in middle Eocene time and rapid sedimentation began, probably 


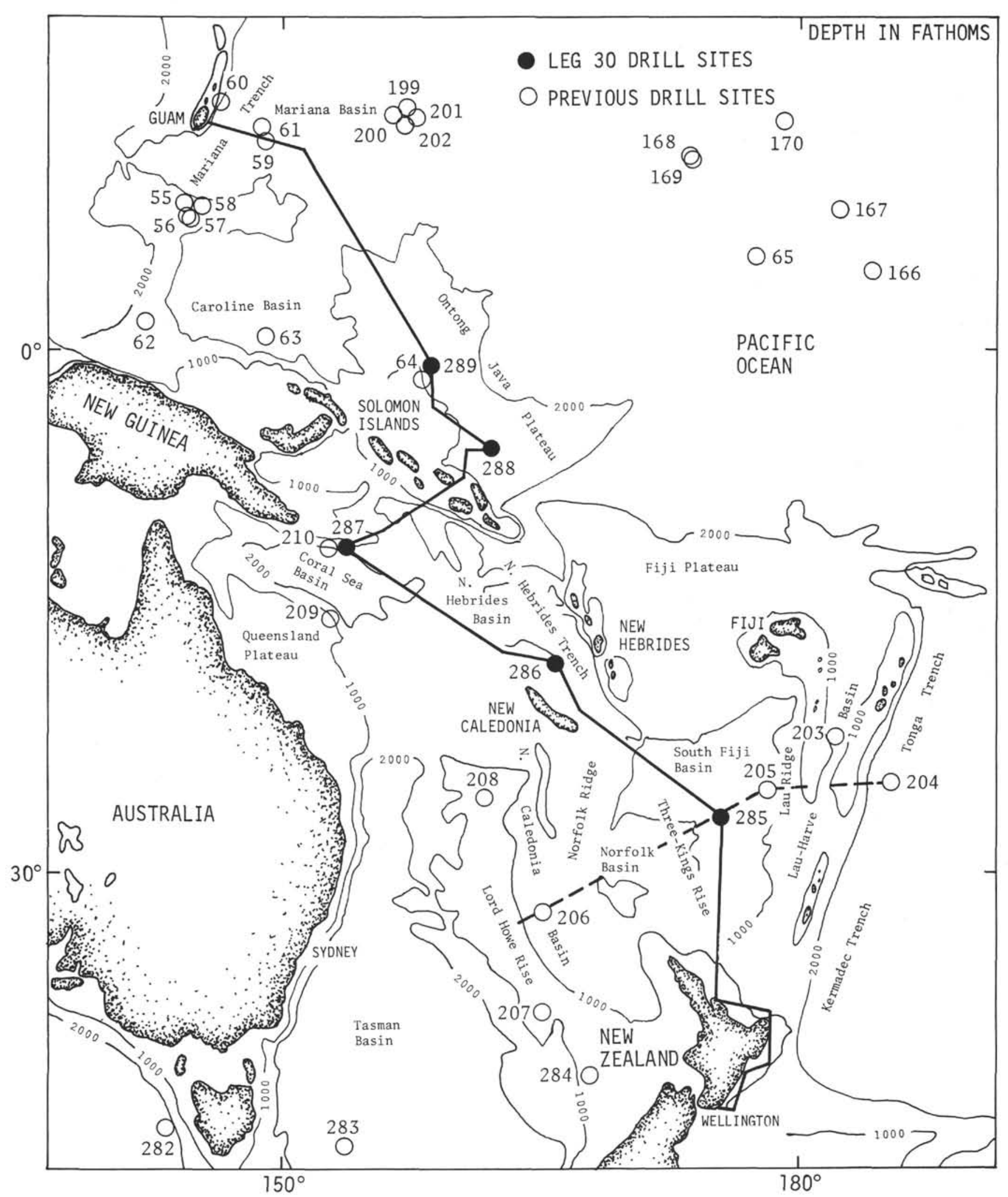

Figure 1. Location of drill sites, DSDP Leg 30 and previous DSDP sites in the region. 
in the form of a submarine fan at the base of a volcanic ridge with active andesitic volcanism until the late Eocene. Sea-floor depth was above the foram solution depth. Much of the material was derived from nearby shallow water. Mainly biogenic sediments with minor ash were deposited in the later late Eocene and Oligocene on a sea floor which has subsided below foram solution depth, but not below nannofossil solution depth. By latest Oligocene time the depths were below nanno solution depths with clay and glass shard ash accumulating. This subsidence is again attributed to cooling of the lithosphere. A period of nondeposition or erosion intervenes before the Pliocene, to be followed in early Pliocene to Pleistocene time by a continuous influx of glass shard ash from fairly distant sources. Reworked fossils, including shallow-water Miocene and Pliocene benthonic neritic species that appear in beds of early Pleistocene age near the top of the section, suggest erosion of nearby older shelf deposits (probably around the New Hebrides) and indicate the blocking of the New Hebrides Trench east of Site 286 by the early Pleistocene. Deformation of the sea floor, seen in seismic profiles, occurred after the deposition of the Eocene clastic sediments but was probably pre-middle Miocene. This deformation can be detected as far south as Site 285 in the South Fiji Basin. Packham and Terrill (this volume) favor a late Eocene or early Oligocene age. The Eocene/Oligocene regional unconformity (Kennett et al., 1972) does not occur at this site indicating that it was structurally isolated probably by the Norfolk Ridge, from the Coral Sea, Lord Howe Rise, and New Caledonia Basin to the west.

In the Coral Sea Basin (Site 287) the section (Chapter 5 , this volume) is quite similar to that sampled at Site 210 (42 km to the west-northwest at Site 287), but shows the effects of the greater distance from the source of the Pliocene and younger clastics (the turbidites are finer grained), and the effect of the basement ridge on which Site 287 was drilled (turbidites appear later due to elevation, the Eocene/Oligocene regional unconformity spans a larger interval, and pelagic sections are thinner at Site 287). The basement ridge that lies immediately south of the site trends northwest-southeast and appears to have developed shortly after the formation of the basin crust in the early Eocene. At first the depth of sedimentation was above foram solution depth, but passed below nannofossil solution depth possibly by late Oligocene and certainly early Miocene. The green silty clay deposited perhaps from the middle Miocene onwards may represent the distal ends of turbidity currents which were at that time beginning to deposit graded rhythms at Site 210. The turbidites built to the level of the sea floor at Site 287 in early Pliocene time. The thickness of Pleistocene turbidites (about $90 \mathrm{~m}$ ) is similar at both sites, as is the frequency of deposition (about one flow per $5000 \mathrm{yr}$ ).

On the Ontong-Java Plateau basement was not reached at Site 288 (see Chapter 6, this volume), but a comparison to Site 289 suggests that the older sediments (Aptian) may not have been far above it.

Following crustal formation in pre- or early Aptian time, biogenic and volcanogenic sediments accumulated. A mid-Cenomanian-early Turonian cycle of volcanogenic sediments may have been derived from the southward-migrating spreading center which formed the crust at Site 289 west of a north-south fracture zone (see below). Maximum depth was reached in the Campanian.

After the reappearance of planktonic foraminifera in the Maestrichtian sediment, the depositional environment remained relatively constant till late Oligocene time. The section is discontinuous, with a major hiatus in the Eocene and lower Oligocene. Reworked sediments suggest that the site has been an unstable surface of gentle inclination-probably a topographic lowwhich had been subject to current scour and minor slumping from Aptian to Miocene. More intense disturbances have occurred from the late Miocene on.

Ash in the upper Pliocene is probably related to volcanism on the Stewart Arch and the Roncador Homocline. The Miocene/Pliocene hiatus may mark slumping associated with tectonism and may reflect collision of the plateau with the Australian plate to the southwest.

At Site 289 (see Chapter 7, this volume) the Pleistocene to early Oligocene is continuous, and contains a diverse microflora and microfauna with good to excellent preservation.

At least six substantial stratigraphic breaks are present in the Lutetian (middle Eocene) and Ypresian; Ypresian and Thanetian (upper Paleocene); Thanetian and Danian (lower Paleocene); lower Danian and Maestrichtian; and Aptian and Campanian. The Eocene/Oligocene break is similar to that reported by Kennett et al. (1972) in the Tasman and Coral seas.

Very minor chert was detected in the lower Miocene with the major appearance in the upper Eocene accompanied by the loss of Radiolaria from the sediments. Less chert was observed at this site than at Site 288. The siliceous and chert-rich strata (Unit 2 of Sites 288 and 289) can be traced between the sites and thickens only at the margin of the plateau (see below).

Plateau elevation has been relatively constant above the foram solution depth, with the exception of a deeper interval, as seen also at Site 288 , in the Campanian.

The Early Cretaceous basement age for Site 288 fits well at the western end of the original Phoenix spreading center (Larson and Chase, 1972). The age at Site 289 requires a fracture zone between Sites 288 and 289 which appears to have been crossed very near Site 288 (see below).

\section{DISCUSSION OF UNDERWAY GEOPHYSICAL DATA}

Seismic reflection (airgun) and magnetic profiles were recorded between sites during Leg 30 . The continuous reflection profiles are presented (Figure 3 ) in three segments as foldouts inside the rear cover of this volume. Segment one illustrates profiles from Great Barrier Island, New Zealand, to Site 286 in the New Hebrides Basin. An essential feature of the structure of the South Fiji Basin can be seen here in the quite regular occurrence of basement ridges and seamounts at about a $65-\mathrm{km}$ interval. The topography and structure of the basin have been discussed in detail by Packham and Terrill (this volume). The north-northeast grain of the 
285

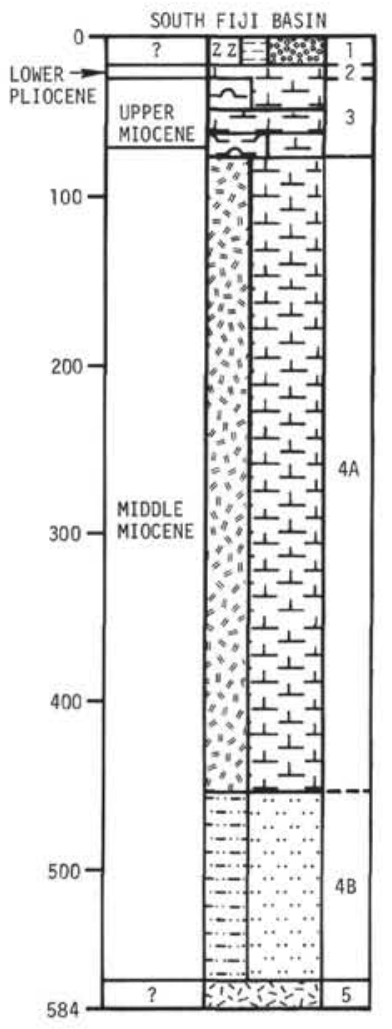

286

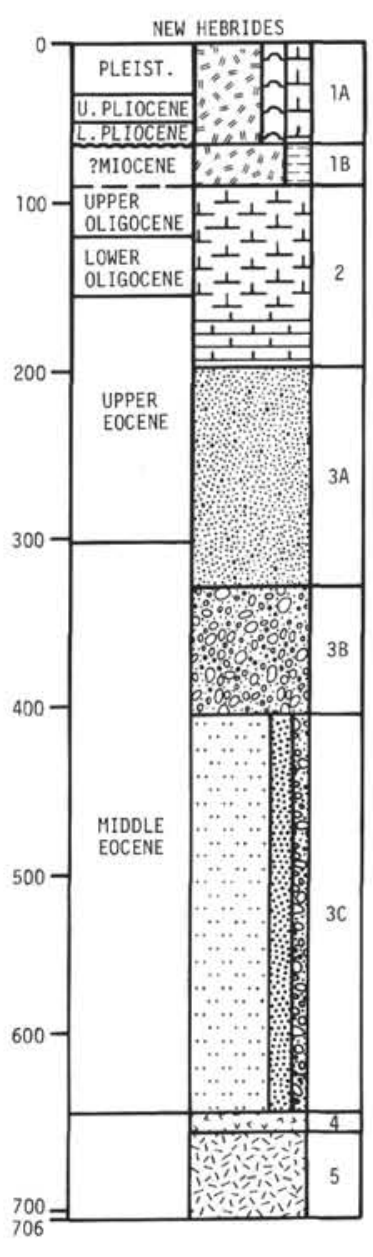

287
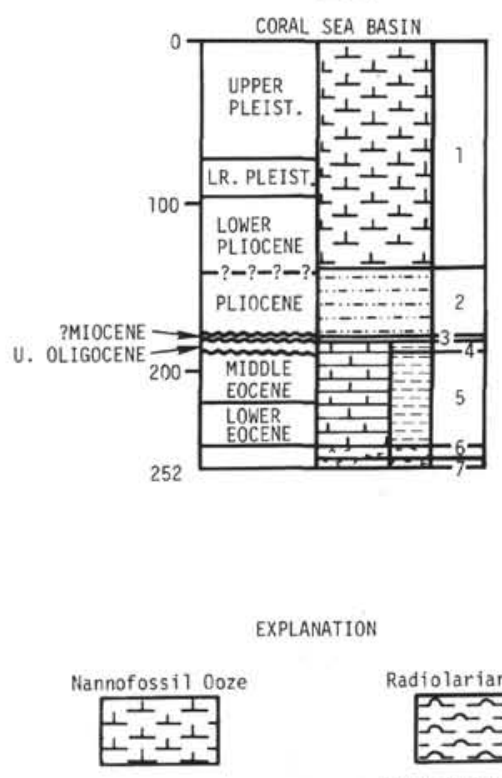

Foraminiferal 0oze
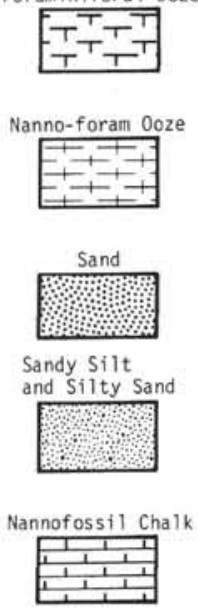

Nanno-foram Chalk
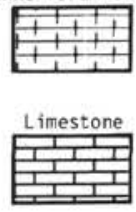

Siliceous Limestone

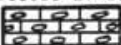

오욜

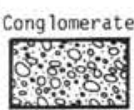

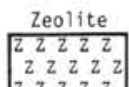

Gabbro and Diabase

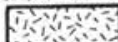

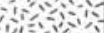

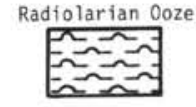

Graded Beds with Biogenic Ooze
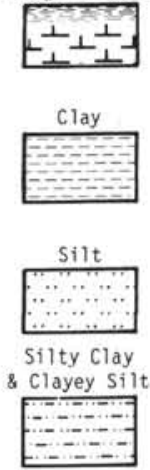

Stratigraphic Hiatus

Micronodules

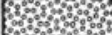
\%

Chert

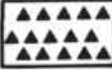

Vitric Tuf

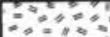

$\therefore: B=-\infty$

Basalt

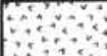

Figure 2. Stratigraphic columns of holes drilled on Leg 30. 
288

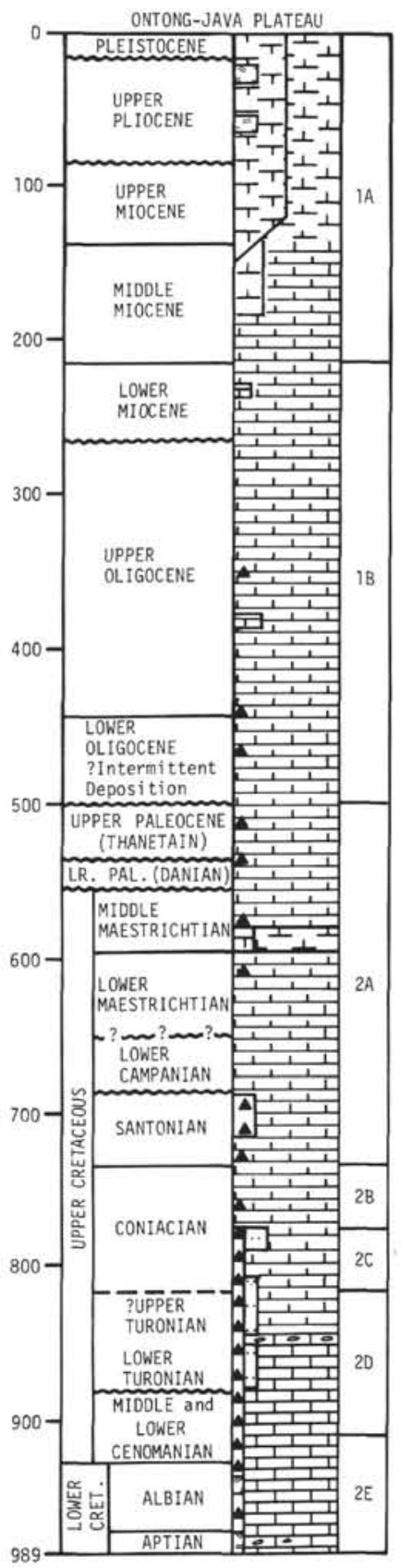

Figure 2. (Continued).

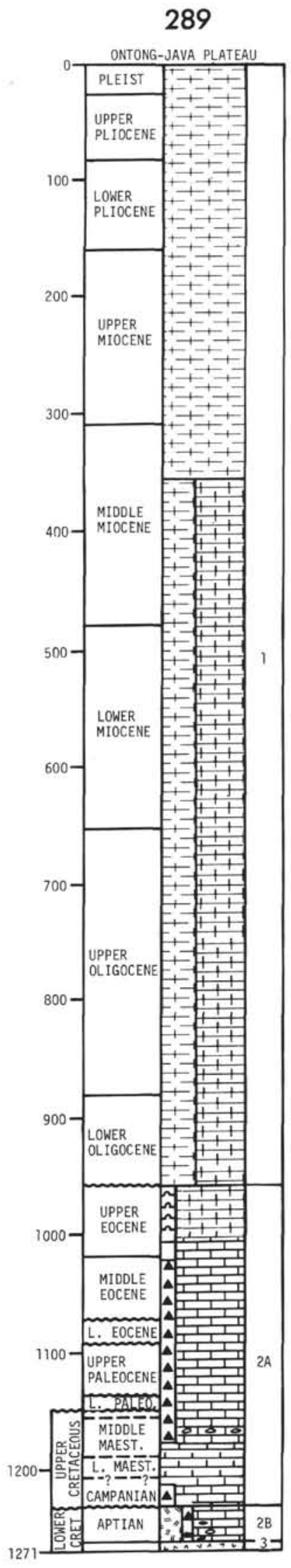


basin may in fact follow from transform patterns related to the spreading episode which formed the basin, although the basement ridges postdate crustal formation in the northwestern part of the basin.

The middle to late Eocene thick volcanogenic sequence at Site 286 can be traced on the profile from Site 286 almost to Site 285 . From Site 286 southward it forms a thinning wedge in the northwestern part of the South Fiji Basin. Further, the sediments can be traced well up the steep flank of the Loyalty Island Ridge without significant thinning. The implications of this are that the New Hebrides Basin and the South Fiji Basin are part of the same body of sea floor, and that the Loyalty Islands were probably not the source of the volcanic detritus, having been uplifted later. Undoubtedly, they were the source of the sediment infill adjacent to them in the northwestern corner of the South Fiji Basin and the southern New Hebrides Basin.

Segment two of the profiles shows the records between Sites 286 and 287 and between Site 287 and the Solomon Islands. Several major fracture zones are present between 286 and 287. From east to west they are the d'Entrecasteaux, Rennell, and Louisiade fracture zones. The first of these separates the easterly deformed part of the New Hebrides Basin from the western part in which the structures are much broader. This fracture zone may have been part of the Pacific-India plate boundary during the obduction of sea floor onto New Caledonia in the early Oligocene (Landmesser et al., this volume). The other two fracture zones may have developed during the formation of the Coral Sea. Alternatively the Rennell Fracture Zone could have been formed as a result of the relocation of the Pacific-India plate boundary after the obduction took place in New Caledonia and been associated with the subduction of part of the Tasman sea floor under eastern Australia. Evidence for subduction was found by Hayes and Ringis (1973). The Eocene to Oligocene pelagic strata seen at Site 287 appear to be continuous over most of the area, supporting the regional interpretation of an Eocene crustal age between these two sites (Landmesser et al., this volume).

One interpretation of the profile from Site 287 towards the Solomon Islands tends to support the hypothesis of marginal basin formation by symmetrical sea-floor spreading from the Coral Sea/New Hebrides Basins (Landmesser et al., this volume). The profile crosses the Louisiade Rise parallel to and south of the Pocklington Trough. The rise has a regular and rather symmetrical cross-section, and the sediment cover thins towards the crest, partly as a result of erosion. The pelagic sediments of the rise can be traced beneath the turbidite fill of the Coral Sea Abyssal Plain, and thus indicate an Eocene age for the sediment cover of the rise. The continuous magnetic profile along this track shows a seemingly symmetrically disposed pattern of magnetic anomalies (Figure 4) and while realizing the limitations of it as a single profile, it is possible to suggest that this is the ridge which generated the Coral Sea crust and possibly the New Hebrides Basin crust as offset by a series of transform faults. A best fit on the anomalies suggests a spreading interval from anomaly 21 to anomaly 17 ( 50 to $46 \mathrm{~m}$.y.B.P.). If this is correct, the age of the sea floor adjacent to the Queensland Plateau could be as old as early Paleocene. The disposition of this ridge is such that the pole of rotation is similar to that for the spreading for the Tasman Sea (Hayes and Ringis, 1973), but at a significant angle to the structural grain of the eastern New Hebrides and South Fiji basins. These differences in direction may imply a sequential or independent development of the marginal basins.

A second interpretation of the Louisiade Rise is that it is composed of continental crust that has been rifted off the Australian continental margin. The seismic profiles resemble typical profiles on the Queensland Plateau (Falvey and Taylor, 1974), and the oldest sediments that fill graben structures could be interpreted as rift valley fills formed at the commencement of rifting. On this hypothesis sea-floor formation would have been essentially confined to the Coral Sea Abyssal Plain area and the region southwest of the eastern section of the Louisiade Rise (Landmesser et al., this volume).

The third segment of the Leg 30 profiles illustrates profiles from the Solomon Islands to Site 288, to Site 289 (via Site 64 of Leg 7, Winterer, Riedel, et al., 1971) and across the Caroline Ridge and Mariana Basin to Guam. Lithostratigraphic continuity is apparent across the plateau, with Units 1 and 2 of Site 288 being traceable to Site 289 and beyond. Unit 2 thickens markedly at the slope break at the margin of the plateau, being nearly three times thicker at Site 288 than at Site 289. These units are time transgressive, being related to chert formation within the section. Between Sites 288 and 289 it appears that a fracture zone was crossed. This feature fits well with the interpretation of the spreading history of the plateau. To the north the plateau deepens before reaching the Caroline Ridge. Crust in the Mariana Basin, north of the Caroline Ridge, is characterized by a thick unresolved basement reflector overlain by thin pelagic sediments. Ages established in the region (as far east as the Mid-Pacific Mountains) by Deep Sea Drilling Project cruises are generally younger than 85 m.y., although it may be that none of the sites have reached true basement. All sites surrounding the region of the Mariana Basin have ages of greater than 100 m.y. This would seem to define the region as an isolated section of younger crust which possibly formed in the same interval as the crust of the Tasman Basin.

Although the profile is interrupted by several ridges and seamounts between Site 289 and the Mariana Basin, it is apparent that the sediment section is thinning continuously away from the margin of the plateau. This is presumably due to the removal of carbonate material at greater depths. Taking some liberties in interpretation, it can be suggested that Unit 2 of the plateau is equivalent to the section which has been sampled in the Mariana Basin. This would imply a greater age for the basin than has been established by drilling.

\section{PLATE MOTIONS}

Magnetic anomaly patterns of the standard oceanic type have been described from the Tasman Sea by Hayes and Ringis (1973) demonstrating that the spreading in the basin occurred from 80 to 60 m.y. B.P. This basin had been regarded by some authors as a marginal basin. 


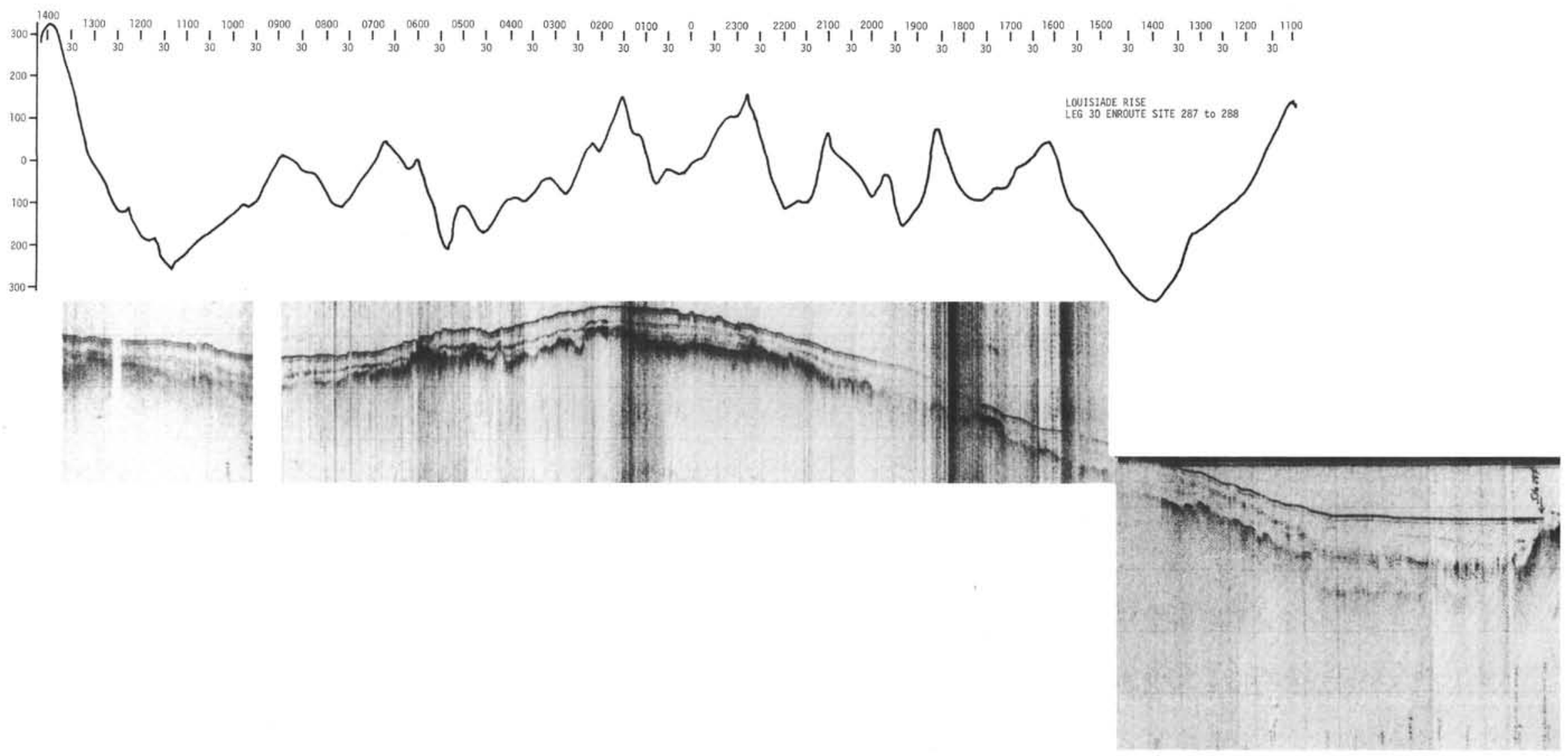

Figure 4. Seismic profile over the Louisiade Rise with observed magnetic anomalies. 
The work of Hayes and Ringis demonstrates that its formation is contemporaneous with spreading on the Albatross Cordillera which commenced between Antarctica and the Campbell Plateau south of New Zealand at the same time (Christoffel and Falconer, 1973). The difference between the anomaly trends as they are at present observed (about $90^{\circ}$ ) is largely if not entirely due to later spreading patterns. The Tasman Sea is on the India plate and the Campbell Plateau is on the Pacific plate. The commencement of spreading of the IndianPacific Ridge between Australia and Antarctica at 55 m.y. B.P. (Weissel and Hayes, 1972) formed oceanic crust south of the Tasman Sea crust with anomaly trends approximately perpendicular to those of the Tasman. This new spreading pattern isolated the southwest Pacific region from the major spreading system of both the Indian and Pacific oceans.

Calculation of stage poles for the India-Pacific plate relative motions from the India-Antarctica stage poles of Weissel and Hayes, 1972, and the Pacific Antarctic stage poles of Molnar et al. (1975) with the India plate held stationary reveals that from 55 m.y. onwards, the poles have moved southwards with time (Packham and Terrill, this volume) (Figure 5, Table 1). The poles back to 29 m.y. are located south of New Zealand, while the older ones are located further north with the 45 to 55 m.y. stage pole located near $160^{\circ} \mathrm{W}$ and $10^{\circ} \mathrm{S}$. The rotation of the Pacific plate is counterclockwise and these pole locations should mean that the amount of subduction and presumably the amount of volcanic activity on the northern part of the arc should decrease with time. From the mid-Eocene to the end of the early Oligocene the line of the present Tonga-Kermadec Trench approximated a transform direction. From the late Oligocene the northern boundary of the arc complex should have become closer to a transform direction. Subduction into the Tonga Trench should have become significant in late Oligocene time and been increasing in rate.

Initially then, plate convergence was greatest on the north side of the arc complex, where Eocene volcanics are best developed and early Oligocene plate convergence is indicated by obduction. In the later history of the region, volcanic activity and convergence should have shifted to the south.

The geological evidence presented is roughly in accord with this except that the changes in trends of the arcs relative to interplate motions have complicated the pattern. So too has the apparent swapping of arcs from one plate to another as arcs have changed their polarities. One of the most conspicuous implications of the motions suggested is that the Ontong-Java Plateau, a region of thick oceanic crust on the Pacific plate (Kroenke, 1972), has moved "westwards" at an increasing rate during the last $55 \mathrm{~m} . \mathrm{y}$. from a position north-northwest of the 45-55 m.y. pole (Figure 5). The collision of the plateau with the arc system demanded by the geometry of the movements has had a profound effect on the present distribution and polarity of arcs as well as the disposition of subduction zones in the later Cenozoic. It has been suggested that the great crustal thickness of the plateau prevented its subduction (Kroenke, 1972; Packham, 1973). Almost all of the "westward" motion has taken place in the last 38 m.y. (since the end of the Eocene).

Molnar et al. (1975), who have provided the most recent analysis of the South Pacific anomalies, attempted a series of reconstructions assuming that the PacificIndia plate boundary ran through New Zealand. Up to 38 m.y. deformation of the New Zealand region is indicated, progressively straightening out the New Zealand geosyncline and bringing the trends of the Tasman Sea and South Campbell Plateau anomalies closer. Their 45-m.y. reconstruction requires substantial overlap between the Campbell Plateau and the Lord Howe Rise. As an alternative, they suggest that opening between east and west Antarctica took place and that there was no interaction along the India-Pacific plate boundary. To put it another way they are suggesting that there was a collision between east and west Antarctica around 38 m.y. ago.

This, however, does not seem to be in keeping with geological observations and seismic profiles in the Ross Sea region (P. Barrett, personal communication), and further their model implies that no active plate boundary existed between the India and Pacific plates prior to 38 m.y. On the contrary, abundant evidence exists in the region for an active Pacific-India plate boundary in the form of island volcanism and the formation of new sea floor in marginal basins. The supposed overlap of the Lord Howe Rise and the Campbell Plateau may be an artifact resulting from Molnar et al. (1975) using the present plate boundary through New Zealand in their reconstructions.

Apart from relocations of subducting plate boundaries associated with suggested reversals of arc polarities, the Pacific-India plate boundary appears to have undergone other modifications: (a) the boundary has been obductive in the Papuan Peninsula (Papuan Ultramafic Belt), New Caledonia, and possibly the Solomon Islands; (b) it has been interpreted as a zone of arc continental margin collision and subsequently a region of folding and strike slip faulting in northern New Guinea; (c) one interpretation of the Rennell Fracture Zone is that it was a short-lived transform fault between the Pacific and India plates.

\section{INTERPRETED GEOLOGICAL HISTORY}

Against the background of the plate motions discussed above, the data collected on Legs 21 and 30 of the Deep Sea Drilling Project, and the regional geology outlined in Chapter 1, the following geological history is proposed. In general, there was extension of the area of the India plate in the early Cenozoic by marginal sea development and reduction of its area in the later Cenozoic due to arc polarity reversals and subsequent plate motions. Most of the additions of new crust in this second phase were to the Pacific plate. This follows the scheme outlined by Packham (1973). It is possible at the present state of knowledge to present only a qualitative account of the plate tectonics.

\section{Cretaceous-Paleocene}

About the middle of the Cretaceous or possibly a little later the Phoenix/Pacific spreading center was located 
in the Bellinghausen Sea and the subduction of the Phoenix plate into a trench on the coast of west Antarctica ceased. The Phoenix plate then became part of the Antarctica plate (Larson and Chase, 1972). The spreading axis at this time was nearly parallel to the
Antarctic Peninsula. When the oceanic crust became fixed to Gondwanaland, the spreading axis was momentarily stationary, then as spreading continued the axis and the Pacific plate moved northwards fracturing the continental margin on the Pacific plate side of the

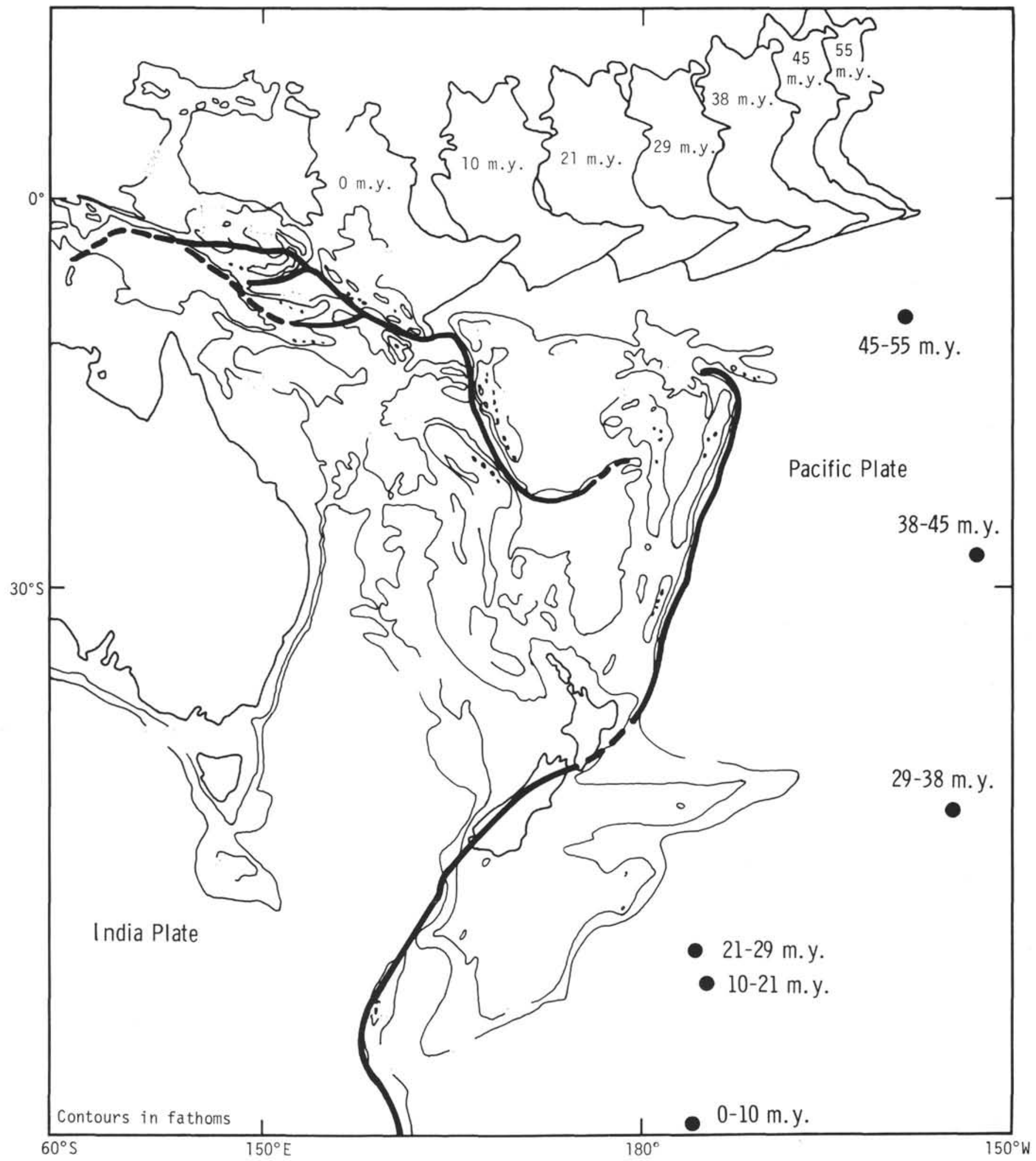

Figure 5. Poles of rotation for Pacific/India plate with the India plate held stationary and reconstructed locations of the Ontong-Java Plateau. 
TABLE 1

Pacific/India Poles of Rotation (India Plate held stationary)

\begin{tabular}{ccc}
\hline $\begin{array}{c}\text { Age } \\
\text { (m.y.) }\end{array}$ & Location & $\begin{array}{c}\text { Anticlockwise } \\
\text { rotation of } \\
\text { Pacific Plate }\end{array}$ \\
\hline $0-10$ & $59.4^{\circ} \mathrm{S}, 175.7^{\circ} \mathrm{W}$ & $11.8^{\circ}$ \\
$10-21$ & $53.2^{\circ} \mathrm{S}, 174.6^{\circ} \mathrm{W}$ & $9.9^{\circ}$ \\
$21-29$ & $51.6^{\circ} \mathrm{S}, 175.5^{\circ} \mathrm{W}$ & $7.5^{\circ}$ \\
$29-38$ & $43.9^{\circ} \mathrm{S}, 156.2^{\circ} \mathrm{W}$ & $7.0^{\circ}$ \\
$38-45$ & $27.2^{\circ} \mathrm{S}, 153.6^{\circ} \mathrm{W}$ & $6.6^{\circ}$ \\
$45-55$ & $9.5^{\circ} \mathrm{S}, 159.7^{\circ} \mathrm{W}$ & $7.6^{\circ}$ \\
\hline
\end{tabular}

spreading axis. Northward motion suggested by Larson and Chase (1972) on the basis of paleolatitude estimates for magnetic anomalies is supported by paleomagnetic measurements of sediments from Site 289 by Hammond et al., this volume. Drilling at Sites 288 and 289 established that the Ontong-Java Plateau basement is late Early Cretaceous in age. This age is a little younger than the youngest of the Phoenix anomalies identified by Larson and Chase to the east of the plateau. Winterer et al. (1974) suggest that they may be separated by transform faults. We are treating the Ontong-Java Plateau as part of the Pacific plate from the Late Cretaceous onwards. Fracturing of the Gondwanaland continental margin involved the rifting of the Campbell Plateau from Antarctica and the Lord Howe Rise from eastern Australia (Christoffel and Falconer, 1973; Hayes and Ringis, 1973). Magnetic anomalies establish that these two events were synchronous commencing 80 m.y. ago, but the present trends of the anomalies are quite different as indicated above. The Campbell Plateau has apparently been rotated with the Pacific plate since the commencement of rifting of Australia from Antarctica (late Paleocene, $55 \mathrm{~m} . \mathrm{y}$. ago) while the Tasman has remained essentially part of the India plate. If the formation of the Tasman Sea from 80 to 60 m.y. (Late Cretaceous to the middle of the Paleocene) is attributable to the westward extension of the Albatross Cordillera, then there was a single spreading axis active in the region and the Tasman Sea is not a marginal sea in the generally accepted sense. The region east of the Tasman spreading ridge would have been part of the Pacific plate. There is no evidence of volcanic evidence of a convergent plate boundary in New Caledonia or northern New Zealand. Tectonically the Tasman Sea resembled the Gulf of California or the Red Sea. Even if the axes did not line up, the two sets of spreading are closely related and the analogy holds. The New Caledonia Basin to the east of the Lord Howe Rise is probably of similar age to the Tasman Sea as is suggested by Leg 21 deep-sea drilling results. Its mode of formation then is different, since it was physically separated from the Tasman Sea spreading center at its time of formation.

Prior to the formation of the Coral Sea the Mesozoic clastic rocks that form the metamorphic spine of the Owen Stanley Range in the Papuan Peninsula occupied a position adjacent to the northern end of the Queensland Plateau. The age of metamorphism was Eocene or older (Davies and Smith, 1971).

\section{Eocene Phase of Marginal Sea Formation}

Eocene sea-floor ages have been obtained in the Coral Sea and the New Hebrides Basin. It appears from the study of seismic profiles that the Eocene episode could include the western part of the South Fiji Basin (Packham and Terrill, this volume). By extrapolation, the Norfolk Basin might also have been formed at this time. The crust between the Coral Sea, the northern Tasman Sea, and the New Hebrides Basin is intersected by several large fractures discussed above, and has in places a thick sediment cover (Landmesser et al., this volume). While it cannot be shown unequivocally that all the crust is oceanic as indicated previously, it is considered by them that the oceanic crust present is probably Eocene. No data are available as to the age of the Solomon Sea floor. Eocene island arc volcanism is known in the region; it occurs in the northern part of New Guinea, New Britain, Fiji, and on Eua (Tonga Islands) and possibly in the New Hebrides (see Chapter 1).

Volcaniclastic sediments and associated shallow water limestones occur in New Guinea, New Britain, inferred for the New Hebrides, and present in Fiji and Eua (Figure 6). Island arc volcanism was associated with the formation of the New Hebrides Basin as indicated by a thick sequence of volcaniclastic rocks resting on the seafloor basement. If the Solomon Sea is of similar age, the Eocene volcanics in New Britain and northern New Guinea may be related to its formation. The location of these various volcanic arcs was probably rather different from what it is now as a result of later plate motions and plate boundary relocations.

From the geometry of motion of the Pacific and India plates relative to the Antarctic plate, it is clear that from the time of commencement of rifting of Australia from Antarctica, there had to be an active plate boundary between the plates. During this time the relative pole of rotation for the India and Pacific plates was apparently near $10^{\circ} \mathrm{S}$ and $160^{\circ} \mathrm{W}$. The boundary had to be convergent along the northern margin of the complex from New Guinea to Fiji where there is the corroborating evidence of the existence of island arcs. Their locations at the time cannot be determined. At the same time as volcanism was taking place, sea floor was being formed in the Coral Sea, the New Hebrides Basin, and possibly the northwestern South Fiji and Norfolk Basins, but in the last (and possibly the last two) the structural fabric is different from the Coral Sea. The only relatively simple, geometric arrangement to explain these relationships is for the subduction zone to be on the northern side of the volcanic arcs and for the arcs to migrate northwards with the velocity of convergence of the two major plates plus an added velocity due to sea-floor formation within marginal seas. The eastern boundary was probably a transform fault. It appears that the width of the new crust produced increased towards the pole position, i.e., as the convergence rate between the Pacific and India plates decreased.

The oldest sea floor dated on Leg 30 within the arc complex is in the Coral Sea and just over $50 \mathrm{~m}$.y. This is only a few million years after the commencement of rifting of Australia from Antarctica and less than 10 m.y. 


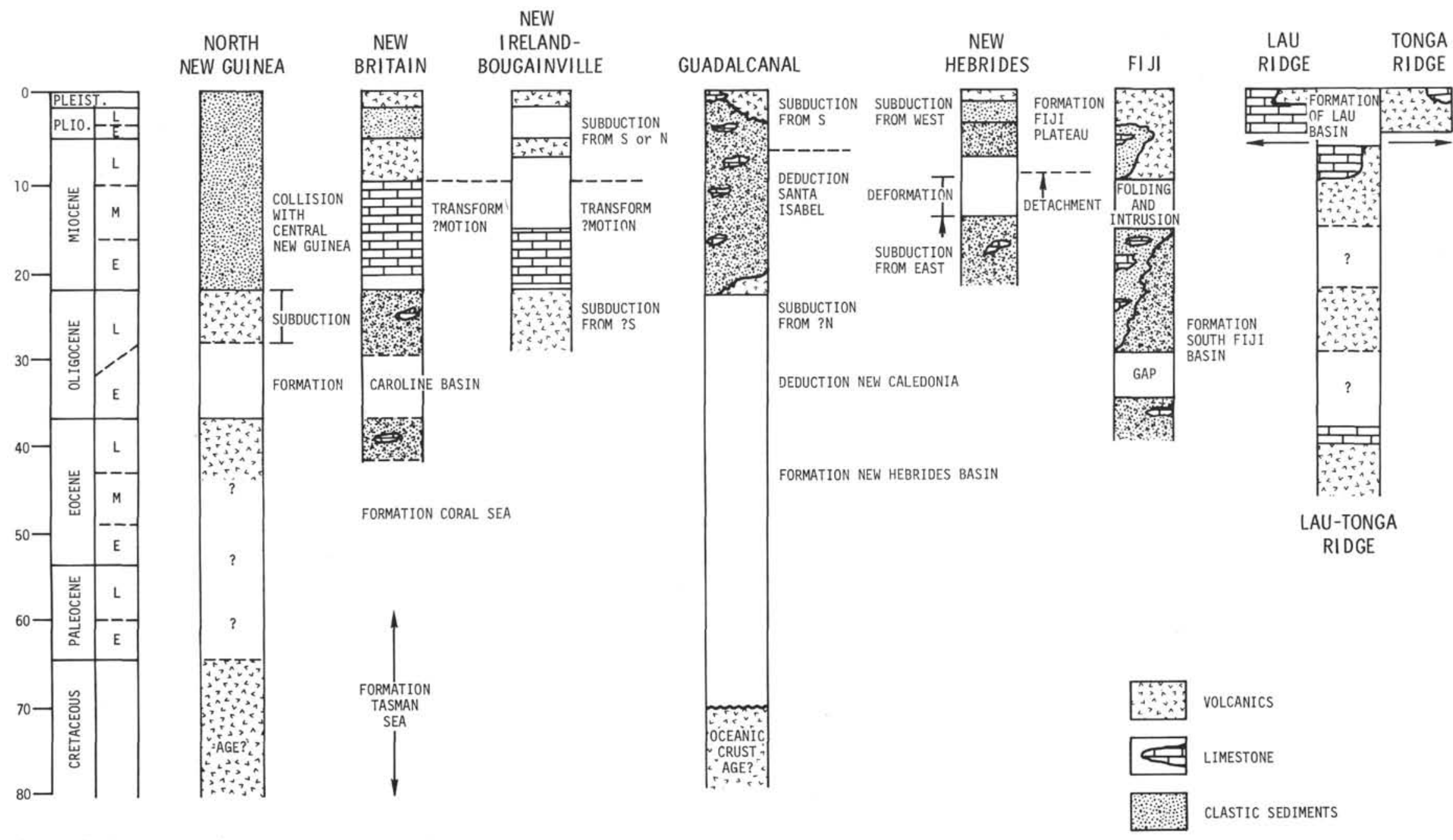

Figure 6. Summary of stratigraphic columns for selected islands in the southwest Pacific. 
younger than the youngest sea floor in the Tasman Sea. As the age of Coral Sea site probably does not represent the greatest age in the basin, spreading in the region could have been continuous temporally but not necessarily geographically. The development of these marginal seas had to be independent of the PacificAntarctic spreading center since sea-floor formation had ceased in the Tasman Sea and the connection severed.

The initiation of the convergent plate boundary, and the commencement of the development of the arcs and the marginal seas all appear to have taken place within a short time span. The details of the process involved are difficult to visualize. The Coral Sea does not have a volcanic arc directly related to it. Its outer limit, represented by the Papuan Peninsula and the Louisiade Island chain, contains metamorphics of continental origin. These same rocks may form the basement of the Rennell Ridge and link up with the Mesozoic metamorphics of New Caledonia (Landmesser et al., this volume). The Eocene volcanic arcs that lie further oceanward have no continental rocks associated with them.

\section{Oligocene Sea-Floor Formation and Tectonism}

Sea floor of Oligocene age is known in the Caroline Basin, north of New Guinea, and in the eastern part of the South Fiji Basin, but it is not known what time span is represented in the formation of these areas of sea floor. An early Oligocene date has been obtained in the Caroline Basin (Winterer, Riedel, et al., 1971) and a date of about the middle of the Oligocene on the eastern side of the South Fiji Basin (Burns, Andrews, et al., 1973).

Two important tectonic events occurred in the Oligocene. The older is the obduction of sea floor onto the island of New Caledonia (almost certainly in the early Oligocene) and perhaps contemporaneous with the obduction of the Papuan Ultramafic Belt onto the $\mathrm{Pa}$ puan Peninsula. Recent unpublished work by the Australian Bureau of Mineral Resources indicates that this probably took place in the early Oligocene rather than the Eocene as suggested by Davies and Smith (1971). The second event at about the end of the Oligocene is what has been interpreted as a collision of an island arc with northern New Guinea. This arc has late Oligocene volcanics associated with it. Development of the Caroline Basin as an accretion onto the Pacific plate could have been responsible for the southward migration of the Eocene-Oligocene volcanic arc comprising New Britain, northern New Guinea, and perhaps including Manus, New Ireland, and ?Bougainville (Figure 6). The velocity of motion of the arc would be the sum of the velocity of convergence of the Pacific and India plates plus that due to spreading in the Caroline Basin. The suggested collision of the arc with northern New Guinea in the Oligocene and the absence of volcanics on the southern block indicate a subduction zone dipping to the north under the volcanic arc. This would appear then to be a mirror image of the situation in the Eocene and implies arc polarity reversal between the two episodes. If the arc polarity of the eastern end of the arc complex (New Hebrides, Fiji, and Tonga) has remained unchanged, the two arc sectors would have been separated by a transform fault. The western section would have been part of the Pacific plate and the eastern section of the India plate.

The eastern and probably the southern parts of the South Fiji Basin are late Oligocene, and their formation may have been initiated after the obduction in New Caledonia. Its development would have carried the Lau Ridge eastwards together with Fiji. The New Hebrides may have also been displaced to the east as part of the same arc (cf. Gill and Gorton, 1973; Packham, 1973) by a new subducted northward extension of this crust. Drilling in the New Hebrides Basin has revealed that there was no deposition of volcanic products in quantity at the site in the Oligocene or the Miocene. The oldest shallow water formations in the New Hebrides are latest Oligocene to basal Miocene. This suggests that building of the arc may have commenced considerably before that time. Since the preponderance of rocks on the islands are early Miocene and possibly older volcanic rocks, and since volcanic debris is absent from the Oligocene and Miocene of the New Hebrides drill site, the New Hebrides are assumed to have been far removed from their present location at that time. Their polarity was probably the opposite of that at present (Gill and Gorton, 1973; Colley and Warden, 1974).

Linking the New Hebrides to the western part of the arc complex are the Solomon Islands in which the Pacific Province typified by Malaita and northern Santa Isabel (Coleman, 1970) consist of oceanic basalts overlain by oceanic sediments (see below). The Solomon Islands of the central province of Coleman (1970) from Choisel to San Cristobal also have a volcanic basement. The basement lavas on Guadalcanal are chemically similar to oceanic tholeiites rather than part of an island arc (Hackman, 1971). It is suggested below that they were part of the Pacific plate either forming part of (or adjacent to) the Ontong-Java Plateau. These islands and those of the Solomon Pacific Province differ from others in the arc complex to the east and west in this regard. The others are built of lavas, volcaniclastics, and shallow water carbonate deposits. The location of the Solomon Islands in the Oligocene is uncertain, but plate motions outlined above would place them substantially to the east of their present position (Figure 5). It is suggested below that they were inserted into the arc at the time of the Oligocene arc reversal suggested above.

Convergence between the Pacific and India plates is indicated by the plate motion vectors in the Oligocene (Figure 5), but there is an increasing westerly component as the pole of rotation moved southward relative to the India plate. As the pole moved south, the zone of crustal accretion to the India plate also moved south into a region of lower convergence rate. The Emerald Basin was added to the Pacific plate at this time also. Although the mode of formation of the eastern part of the South Fiji Basin is not clear, arc migration to the east would have involved only a small amount (around $400 \mathrm{~km}$ ) of subduction (equal to the basin width). During the early Oligocene the interplate motion along the boundary marked by the present Lau-Tonga Ridge trend would have been transcurrent in the south, but with increasing convergence to the north. This may explain why volcanic material is not abundant in the late Oligocene section at Site 205. 


\section{Miocene and Later}

The early to middle Miocene was an interval in which there was widespread deposition of limestone in New Britain and New Ireland and Bougainville, but in the Solomons clastics were common including detrital serpentinites (Coleman, 1970). In the Pacific province of the Solomon Islands as exemplified by Malaita, the oceanic basaltic basement is overlain by Albian to Pliocene deep water sediments (Deventer and Postuma, 1973). Upper Miocene and younger sediments of the province contain increasing amounts of terrigenous detritus, but this detritus is missing from the otherwise similar section on the Ontong-Java Plateau (Sites 288 and 289). The Miocene of the central province contains abundant shallow water deposits. The juxtaposition of these two features and the presence of large bodies of serpentinite along the Korigole Thrust and the presence of flat-lying sheets of serpentinite on Choisel make it likely that part of the crust of the Ontong-Java Plateau and its sedimentary cover have been obducted from the north onto the central province (L. Kroenke, personal communication). This probably occurred in the early Miocene and may indicate a further relocation of the Pacific-India plate boundary. Uplift of the central province and the deposition of clastics in the Miocene could be regarded as a response to the obduction. The presence of the late Oligocene or basal Miocene Suta Volcanics on Guadalcanal may indicate that the obduction was preceded by some subduction.

The absence of volcanics and clastics from the early to middle Miocene on the islands from Bougainville westwards may indicate that they were oriented parallel to the transform direction between the India and Pacific plates. The location of the plate boundary would determine whether the islands were being moved with the Pacific or the India plate, but it appears that they were essentially moving with the Pacific plate (see below). Change of arc orientation may have been the result of the development of subplates in the region following the late Oligocene collision of the arc with northern New Guinea. These small plates may have been the precursors of the ones identified in the region by Johnson and Molnar (1972). The part of the arc west of Manus Island was probably originally attached to New Britain. Strike slip faulting is still taking place in the Bismarck Sea.

By late Oligocene time, the pole of relative rotation for the Pacific and India plates had moved south of New Zealand (Figure 5), and there was an increasingly rapid relative westward motion of the Pacific plate carrying the Ontong-Java Plateau with it. The supposed obduction in the Solomon Islands could have been in some way a response to their interaction with the remaining probably north-facing part of the arc complex, namely the New Hebrides and Fiji islands (see below). Alternatively, and more likely, it was related to plate boundary readjustments following the collision of the arc system with northern New Guinea in the Oligocene, occurring immediately before or contemporaneously with the suggested detachment of the end of the arc west of Manus Island from New Britain. Subsequently the arc segment has moved westward on the Pacific plate pro- gressively overlapping New Britain and northern New Guinea.

Following the collision of the Oligocene arc and accompanying the suggested westward motion of the remainder of the arc, elevation of the northern part of New Guinea took place, and widespread clastic deposition occurred accompanied in the middle Miocene by volcanic and plutonic activity. Probably as a consequence of the small plate interactions, elevation of the Papuan Peninsula commenced in the early Miocene, resulting in an inflow of clastic sediment into the Aure Trough, and in the middle Miocene into the Coral Sea. Continuation of motion probably resulted in the folding of the Aure Trough in the Pliocene. Arc reorientation and spreading in the Woodlark Basin accompanied by some change in relative India-Pacific plate vectors lead to renewed subduction and further volcanic activity in the arc from the Solomons to New Britain with subduction occurring on the south side of the arc.

As is pointed out by Johnson et al. (1973), all of the volcanic activity in the late Cenozoic especially in New Guinea cannot be related to presently recognizable subduction zones. An anomalous association of calcalkaline and shoshonitic volcanics occurs in northern and eastern Papua.

In the more easterly part of the arc system in the New Hebrides it has been argued by Mitchell and Warden (1972) and others that the present polarity of the arc was developed in the middle Miocene possibly as a result of interaction with the Ontong-Java Plateau-Solomon Islands (Packham, 1973), then as the younger sea floor of the Fiji Plateau formed the New Hebrides moved westwards to its present position severing its connection with Fiji (Chase, 1971) and blocking the central part of the New Hebrides trench at least by the early Pleistocene. At present spreading rates this would have taken place when the New Hebrides were about $200 \mathrm{~km}$ west of their present position. The probability that the East Rennell Island Ridge continued further to the east is high. It is likely then that the present configuration of the trench with the ridge intersecting it and physically blocking its central region is a steady-state situation. This is supported by the lack of break in seismicity. It would appear then that tectonic erosion was taking place with segments of the ridge being subducted. This process may have commenced by the early Pliocene when the first sediments derived from the New Hebrides were deposited at Site 286. At that time the arc would have been about $400 \mathrm{~km}$ to the east.

The change from calcalkaline to shoshonitic volcanism in Fiji during the Pliocene (Gill and Gorton, 1973) has been attributed to the increased distance of the islands from the trench to the east as the Lau Basin formed splitting the arc.

Contemporaneous with the suggested reversal of the polarity of the New Hebrides Arc, subduction rates in the Tonga Trench increased and accompanying volcanism resulted in the thick volcanogenic accumulation of sediment in the Minerva Abyssal Plain of the South Fiji Basin being deposited. The sediment of the Kupe Abyssal Plain of the southern part of the South Fiji Basin is probably attributable to the volcanic activity in 
Northland in northern New Zealand in the early Miocene and the late Miocene to Pliocene on the Coramandel Peninsula.

The Fiji Plateau has been clearly accreted onto the Pacific plate, and the New Hebrides arc has moved westward consuming some of the Eocene and possibly Oligocene sea floor of the New Hebrides Basin. There may be some analogy between the accretion of the Caroline Basin and the Fiji Plateau onto the Pacific plate.

The Lau-Havre Trough has been documented by Karig (1970) and is a good example of arc migration by addition to the India plate. The Woodlark Basin (Luyendyk et al., 1973) may be different from the other features discussed here. It is a small area of crust developed in a region of complex motions and incipient collisions. The crust generated there appears to be a response of the motions of the surrounding plates. It is important to note that the formation of the crust is not a function of arc development.

\section{MECHANISM OF MARGINAL SEA GENERATION}

Although drilling on Leg 30 has provided key data enabling the foregoing tentative tectonic synthesis of the southwest Pacific arc complex to be presented, it has not directly contributed to the resolution of the question of the mechanism of generation of marginal seas. Whether the sea floor is generated symmetrically or asymmetrically cannot be demonstrated with the limited drilling information. There are indications of possible symmetrical spreading centers in several basins. In particular one interpretation of the structure of the Louisiade Rise is a spreading center for the Coral Sea Basin. In the South Fiji Basin the pronounced and regular trend of the basement ridges suggests transform structures with a north-northwest trending ridge. Although the basement ridges postdate the formation of the crust (Packham and Terrill, this volume), they may parallel the original structure. Arguments were presented for either a two phase symmetrical or a one sided (asymmetrical) spreading history. In the latter case the crust of the basin would have been developed by an eastwards moving ridge. The patterns of basin development are sufficiently similar to each other in trend and to the ridge which generated the Tasman Sea to suggest possible continuation of activity of the Tasman Ridge independent of the spreading in the Pacific. Closely spaced intrusive structures and fracture zones may easily obscure magnetic anomaly patterns that would more clearly define spreading patterns, accounting for poor anomaly correlation in the basins. On the present data kinematic solutions are not possible. The wavelength of magnetic anomalies in the marginal basins suggests that some regular process is involved.

It appears from the preceding discussion that arc migration is usually associated with marginal sea development, although not in the sense popularly accepted. That is, that arc migration should be viewed as an effect of the development of marginal seas (cf Packham and Falvey, 1972), rather than as a cause of this development (cf. Karig, 1971). Zones of expansion of the India plate tended to migrate southwards with the pole of rotation for the Pacific and India plates. It appears to be greater where convergence rates are lower or even transform or divergent relative motions occur. Concurrent expansion of the Pacific plate has not followed as regular a pattern (see Table 2). In Eocene time while the Coral Sea, New Hebrides Basin, Solomon Sea, and perhaps the western South Fiji Basin were added to the India plate there were no additions to the Pacific plate. While accretion on the Indian plate moved south in the Oligocene to the South Fiji Basin, accretion on the Pacific plate occurred in the Caroline Basin to the north, and on a much smaller scale in the Emerald Basin to the south. From late Miocene to Recent the LauHavre Basin and the anomalous (?hernia-like) Woodlark Basin have been added to the India plate, while the Fiji Plateau has been added to the Pacific plate. Thus the two major additions to the Pacific plate also show the southward displacement of activity with time, paralleling the motion of the relative pole of motion.

Generation of the basin crust by a thermal diapir (Karig, 1971) would be expected to produce asymmetric spreading or a basin of limited size. It also implies that the basin is a function of the prior existence of a subduction zone, and thus that it is a direct consequence of convergence of major crustal plates. This same cause/effect relationship is implied if arc migration is described as the result of migration of the flexure point of the subducted crust through the mechanism of heavy lithosphere sinking on a trajectory steeper than the angle of the plate (Moberly, 1972).

Marginal sea development as a consequence of arc migration calls for maximum growth of the basins immediately adjacent to zones of maximum convergence rates. In contradiction, we see the location of maximum basin development tending to follow the pole of rotation, i.e., moving towards the zone of lesser convergence. Further, the orientation of the plate boundary at the onset of marginal basin growth may range from normal to the major plate motion (convergence occurring-Lau-Havre Trough) to parallel to them (transform motion along the boundary-South Fiji Basin).

It does not appear valid that the basins are a direct result of island arc development, particularly as the marginal seas can develop on either side on a convergent plate boundary independent of the plate boundary

TABLE 2

Areas and Times of Crustal Accretion to the India and Pacific Plates

\begin{tabular}{lll}
\hline & \multicolumn{1}{c}{ India Plate } & Pacific Plate \\
\hline Eocene & $\begin{array}{l}\text { Solomon Sea, Coral Sea, } \\
\text { New Hebrides Basin, } \\
\text { W.S. Fiji Basin (?) }\end{array}$ & - \\
Oligocene & E.S. Fiji Basin & Caroline Basin, \\
E. Miocene & & Emerald Basin \\
$\begin{array}{c}\text { L. Miocene- } \\
\text { Present }\end{array}$ & $\begin{array}{l}\text { Lau Havre Basin, } \\
\text { Woodlark Basin }\end{array}$ & Fiji Plateau \\
\hline
\end{tabular}


orientation, and may appear in successive episodes to produce arc polarity reversals as with the suggested Coral Sea-Caroline Basin succession. Because of the variety of patterns described, the crust of the marginal basin is seen as being a result of movement within the asthenosphere and its interaction with lithosphere of varying (and changing) structure and buoyancy in the vicinity of a convergent or transform plate boundary.

\section{REFERENCES}

Andrews, J.E., Packham, G.H., et al., 1973. Southwest Pacific structures; Leg 30 Deep Sea Drilling Project: Geotimes, v. 18 , p. 18.

Burns, R.E., Andrews, J.E., et al., 1972. Glomar Challenger down under: Deep Sea Drilling Project, Leg 21: Geotimes, v. 17, p. 14.

Burns, R.E., Andrews, J.E., et al., 1973. Initial Reports of the Deep Sea Drilling Project, Volume 21: Washington (U.S. Government Printing Office).

Chase, C.G., 1971. Tectonic history of the Fiji Plateau: Geol. Soc. Am. Bull., v. 82 , p. 3087.

Christoffel, D.A. and Falconer, R.K.H., 1973. Changes in the direction of sea floor spreading in the south-west Pacific: Oceanography of the South Pacific 1972: New Zealand National Commission for UNESCO, Wellington, p. 241.

Coleman, P.J., 1970. Geology of the Solomon and New Hebrides Islands, as part of the Melanesian Re-entrant, southwest Pacific: Pacific Sci., v. 26, p. 289.

Colley, H. and Warden, A.J., 1974. Petrology of the New Hebrides: Geol. Soc. Am. Bull., v. 85, p. 1635.

Davies, H.L. and Smith, I.E., 1971. Geology of eastern Papua: Geol. Soc. Am. Bull., v. 82, p. 3299.

Deventer, J. van and Postuma, J.A., 1973. Early Cenomanian to Pliocene deep sea sediments from north Malaita: Geol. Soc. Australia J., v. 20, p. 145.

Falvey, D.A. and Taylor, L.W.H., 1974. Queensland Plateau and Coral Sea Basin: structural and time-stratigraphic patterns: Australia Soc. Explor. Geophys., v. 5, p. 123.

Gill, J.B. and Gorton, M., 1973. A proposed geological and geochemical history of eastern Melanesia. In Coleman, P.J. (Ed.), The Western Pacific: island arcs, marginal seas and geochemistry: Nedlands, Western Australia (Western Australia University Press), p. 543.

Hackman, B.D., 1971. Regional geology of Guadalcanal: a contribution to the study of fractured island arcs: Ph.D. Thesis, University of Western Australia.

Hayes, D.E. and Ringis, J., 1973. Seafloor spreading in the Tasman Sea: Nature, v. 243, p. 454.

Johnson, R.W., Mackenzie, I.E., Smith I.E., and Taylor, G.A.M., 1973. Distribution and petrology of late Cenozoic volcanoes in Papua New Guinea. In Coleman, P.J. (Ed.), The Western Pacific: island arcs, marginal seas and geochemistry: Nedlands, Western Australia (Western Australia University Press), p. 523.
Johnson, T. and Molnar, P., 1972. Focal mechanisms and plate tectonics in the southwest Pacific: J. Geophys. Res., v. 77, p. 5000 .

Karig, D.E., 1970. Ridges and basins of the Tonga-Kermadec Island arc system: J. Geophys. Res., v. 75, p. 239.

1971. Origin and development of marginal basins in the western Pacific: J. Geophys. Res., v. 76, p. 2542.

Kennett, J.P., Burns, R.E., Andrews, J.E., Churkin, M., Davies, T.A., Dumitrica, P., Edwards, A.R., Galehouse, J.S., Packham, G.H., and van der Lingen, G.J., 1972. Australia-Antarctica continental drift, paleocirculation changes and Oligocene deep-sea erosion: Nature Phys. Sci., v. 239 , p. 51 .

Kroenke, L.W., 1972. The geology of the Ontong-Java Plateau: Hawaii Inst. Geophys. Rept. HIG-72-5.

Larson, R.L. and Chase, C.G., 1972. Late Mesozoic evolution of the western Pacific Ocean: Geol. Soc. Am. Bull., v. 83, p. 3627.

Luyendyk, B.P., Bryan, W.B., and Jezek, P.A., 1974. Shallow structure of the New Hebrides Island arc: Geol. Soc. Am. Bull., v. 85 , p. 1287.

Luyendyk, B.P., MacDonald, K.C., and Bryan, W.B., 1973. Rifting history of the Woodlark Basin in the southwest Pacific: Geol. Soc. Am. Bull., v. 84, p. 1125.

Mitchell, A.H.G. and Warden, A.J., 1972. Geological evolution of the New Hebrides Island Arc: J. Geol. Soc., v. 127, p. 501 .

Moberly, R., 1972. Origin of lithosphere behind island arcs, with reference to western Pacific: Geol. Soc. Am. Mem., 132 , p. 35.

Molnar, P., Atwater, T., Mammerickx, J., and Smith, S.M., 1975. Magnetic anomalies, bathymetry and tectonic evolution of the South Pacific since the Late Cretaceous: Geophys. J. Roy. Astron. Soc., v. 40, p. 383.

Packham, G.H., 1973. A speculative Phanerozoic history of the southwest Pacific. In Coleman, P.J. (Ed.), The Western Pacific: island arcs, marginal seas and geochemistry: Nedlands, Western Australia (Western Australia University Press), p. 369.

Packham, G.H. and Falvey, D.A., 1971. An hypothesis for the formation of marginal seas in the western Pacific: Tectonophysics, v. 11 , p. 79.

Sclater, J.G., Hawkins, J.W., Mammerickx, J., and Chase, C.G., 1972.. Crustal extension between the Tonga and Lau Ridges; petrological and geophysical evidence: Geol. Soc. Am. Bull., v. 83 , p. 2562.

Weissel, J.K., and Hayes, D.E., 1972. Magnetic anomalies in the Southeast Indian Ocean. Antarctic Res. Ser., v. 19, Antarctic Oceanology II: The Australian-New Zealand Sector: Am. Geophys. Union, p. 165.

Winterer, E.L., Riedel, W.R., et al., 1971. Initial Reports of the Deep Sea Drilling Project, Volume 7: Washington (U.S. Government Printing Office).

Winterer, E.L., Lonsdale, P.F., Matthews, J.L., and Rosendahl, B.R., 1974. Structure and acoustic stratigraphy of the Manihiki Plateau: Deep-Sea Res., v. 21, p. 793. 